\title{
SYNTHESIS, STRUCTURE AND PROPERTIES OF THE GRAFTED PEPTIDOMIMETIC POLYMER BRUSHES BASED ON POLY(N-METHACRYLOYL-L-PROLINE)
}

\author{
Maria Tokareva ${ }^{1}{ }^{凶}$, Halyna Ohar ${ }^{1}$, Stanislav Tokarev ${ }^{1}$, Yuriy Stetsyshyn $^{1}$
}

https://doi.org/10.23939/chcht15.01.026

\begin{abstract}
A new approach to synthesis at the aminated glass surface of novel biocompatible polymeric nanolayers consisting of poly(N-methacryloyl-L-proline) brushes has been developed. Formation of the polymer nanolayers has been realized in several stages. At the first stage, the glass surface has been modified by aminosilane (APTEC), afterwards monolayer of the peroxidecontaining initiator (PI) based on pyromellitic acid has been tethered to this aminated surface. The immobilized PI has been used further for initiation of the grafting "from the surface" polymerization of N-methacryloyl-L-proline for obtaining of the peptidomimetic polymer brushes. Features of the reactions, as well as optimal conditions for performing the process are highlighted in this work. Presented here poly(N-methacryloyl-L-proline) grafted brush coatings are promising material for numerous applications in nanomedicine, especially for production of implants and systems of the controlled interaction with proteins and cells.
\end{abstract}

Keywords: synthesis of polymer nanolayers, "grafting from" polymerization, polymer brushes, poly(N-methacryloyl-L-proline), surface modification.

\section{Introduction}

During the last years, intensive efforts have been devoted to the strategy of formation of "smart" and "biomimetic" coatings [1-7]. Particularly, there is an increased interest in surfaces modified by the grafted polymer brushes which can change their affinity toward proteins and cells under external stimuli [1-3] and therefore have potential applications in biology and medicine. Research area belonging to development of biocompatible materials has been focused on bioactive surfaces capable to interact with a variety of biological systems. A strong progress in chemistry of the grafted polymer brushes grafted [8-13] initiated the study of their properties.

\footnotetext{
${ }^{1}$ Lviv Polytechnic National University,

12, S. Bandery It., 79013 Lviv, Ukraine

Mariia.O.Tokarieva@lpnu.ua

(c) Tokareva M., Ohar H., Tokarev S., Stetsyshyn Y., 2021
}

Synthetic peptide-mimetic polymers represent special interest for applications in grafted polymer brushes. The incorporation of amino-acid residues, which are the constitutional components of proteins, into synthetic polymers draws growing attention because such combination may lead to creation of new non-biological macromolecules with biomimetic properties [14]. The synthesis and characterization of polymers of amino acids $\mathrm{N}$-acryloyl derivatives have been significantly developed by the group headed by T. Endo, who has synthesized and characterized acrylamides with various amino-acid moieties in the side chains [14-18, 19-21]. Polymers that have been synthesized from derivatives of L-proline exhibited thermo-responsive or dual-stimuli $\mathrm{pH}$-and thermo-responsive properties [14-18]. Recently, thermoresponsive properties have also been described for poly(N-acryloyl-L-valine), which are characterized by the lower critical solution temperature close to $282 \mathrm{~K}$ [22]. Additionally, various hydrogels based on polymers of methacryloyl-L-alanine ethyl ester have been successfully synthesized [23, 24]. These homopolymer gels are highly swollen in the temperature range from 273 to $283 \mathrm{~K}$ and collapsed above $303 \mathrm{~K}$, with the midpoint of the transition from a swollen to a collapsed phase at $293 \mathrm{~K}$.

In our previous work [25], we reported on the novel dual-stimuli-responsive grafted brush coatings of poly(N-methacryloyl-L-leucine) (PNML) which were successfully fabricated via polymerization from peroxide initiator grafted to pre-modified glass substrate. Chemical composition and thickness of PNML coatings were determined using time of flight-secondary ion mass spectrometry and ellipsometry, respectively. PNML coatings exhibit thermal response of the wettability between 277 and $301 \mathrm{~K}$, which indicates a transition between hydrated loose coils and hydrophobic collapsed chains. Morphology of the PNML coating was observed with the AFM, transforming with increasing temperature from initially relatively smooth surface to rough and more structured surface. Protein adsorption observed by fluorescence microscopy for model proteins (bovine serum albumin and lentil lectin labeled with fluorescein 
isothiocyanate) at transition from 278 to $298 \mathrm{~K}$, showed high affinity of PNML coating to proteins at all investigated temperatures and $\mathrm{pH}$. Thus, PNML coatings have significant potential for medical and biotechnological applications as protein capture agents or functional replacements of antibodies ("plastic antibodies"). The high proliferation growth of the human embryonic kidney cell (HEK 293) on PNML coating was demonstrated, indicating its excellent cytocompatibility.

Motivated by the strong progress in "biomimetic" coatings [25-27] here we continue to develop previously presented strategy for the fabrication of the grafted brush coatings with synthetic peptide-mimetic polymers. The main goals of our work are synthesis of N-methacryloylL-proline monomer and fabrication of poly(N-methacryloyl-L-proline) - (PNMP) grafted brush coatings on the surface of previously peroxided glass. In addition, the properties of the grafted nanolayers have been studied in detail.

\section{Experimental}

\subsection{Materials}

3-Aminopropyltriethoxysilane (APTES); proline with the content of the main substance $99 \%, M r=$ $=115.13 \mathrm{~g} / \mathrm{mol} ; d^{20}=1380 \mathrm{~kg} / \mathrm{m}^{3}$; and methacryloyl chloride with the content of the main substance $97 \%$, $M r=104.54 \mathrm{~g} / \mathrm{mol} ; d^{20}=1070 \mathrm{~kg} / \mathrm{m}^{3}-$ all were supplied by Sigma-Aldrich. Organic solvents from diverse sources were purified as reported by Riddick et al. [28].

Tert-butyl hydroperoxide was obtained as described in [29] and purified by vacuum rectification, the fraction boiling in the temperature range of 318-320 K (at $1.6 \mathrm{kPa}$ ) was collected. The final product had the refractive index $n_{D}^{20}=1.4002 \pm 0.0002$ (in accordance with previous report $n_{D}^{20}=1.4010$ [30]).

\subsection{Synthesis of Pyromellitic Acid Tetrachloroanhydride}

In a $500 \mathrm{ml}$ round-bottomed flask equipped with a thermometer and a reflux condenser, connected with water scrubber, $43.6 \mathrm{~g}(0.2 \mathrm{~mol})$ of pyromellitic dianhydride and $91.6 \mathrm{~g}(0.44 \mathrm{~mol})$ of $\mathrm{PCl}_{5}$ were mixed and boiled in the oil bath until the mixture became homogeneous. Afterwards, it was additionally mixed for $15-16 \mathrm{~h}$ at $403-408 \mathrm{~K}$. The reflux condenser was then replaced by a Liebig condenser and approximately 60 $63 \mathrm{~g}$ of $\mathrm{POCl}_{3}$ was distilled off during $8 \mathrm{~h}$. Then the temperature of the mixture was increased to $453-458 \mathrm{~K}$. The crude product was recrystallized then from gasoline yielding $51.2 \mathrm{~g}(78.1 \%)$ of a colorless crystalline product with the melting point at $340 \mathrm{~K}$ (in accordance with the literature value of $341 \mathrm{~K}$ [31]) and acid number $\mathrm{AN}=1373 \mathrm{mg} \mathrm{KOH} / \mathrm{g}$ (calculated value $1368 \mathrm{mg} \mathrm{KOH} / \mathrm{g}$ ).

\subsection{Synthesis of Dichloroanhydride of Di-tert-Butylperoxy Pyromellitate} (Peroxide Containing Initiator (PI))

$4.6 \mathrm{~g}(0.014 \mathrm{~mol})$ of pyromellitic acid chloride were dissolved in $15 \mathrm{ml}$ of anhydrous dichloroethane, placed in three-necked flask equipped with stirrer, and $2.52 \mathrm{~g}(0.028 \mathrm{~mol})$ of tert-butyl hydroperoxide were added. The mixture was cooled down to $278 \mathrm{~K}$, and then $2.2 \mathrm{~g}(0.028 \mathrm{~mol})$ of pyridine, dissolved in $10 \mathrm{ml}$ of anhydrous dichloroethane, were added dropwise at $278 \mathrm{~K}$. Then the suspension was mixed for $1 \mathrm{~h}$ while the temperature was raised gradually up to the room temperature. The precipitate of pyridinium chloride was filtered out. The solvent was distilled out and the pellet was dried in vacuum $(100-200 \mathrm{~Pa})$ at $313 \mathrm{~K}$ for $3 \mathrm{~h}$, yielding $8.2 \mathrm{~g}(81 \%)$ of peroxide. The pellet had a yellowish resin-like appearance. Its characteristics are summarized as follows: content of active oxygen is $1.9 \%$ (calc. $2.2 \%$ ); content of active chlorine is $5.4 \%$ (calc. $4.9 \%$ ); $\mathrm{AN}=163.1 \mathrm{mg} \mathrm{KOH} / \mathrm{g}$ (calc. $155.3 \mathrm{mg} \mathrm{KOH} / \mathrm{g}$ ); infrared spectra showed characteristic bands of $v(\mathrm{C}=\mathrm{O})$ in $\mathrm{Ar}-\mathrm{C}(\mathrm{O}) \mathrm{Cl}, \quad v(\mathrm{C}=\mathrm{O})$ in ester group at 1760 and $1752 \mathrm{~cm}^{-1}$; doublet at 1390 and $1365 \mathrm{~cm}^{-1}$, referred to $\mathrm{d}\left(\mathrm{C}_{(}\left(\mathrm{CH}_{3}\right)_{3}\right)$ and a band of tert-butoxy group at $848 \mathrm{~cm}^{-1}$. For all samples ${ }^{1} \mathrm{H}$ NMR spectra were recorded using a "Varian VXR" spectrometer ( $\mathrm{H}$ chemical shifts are expressed in 1-scale relative to internal standard tetramethylsilane as integrated intensities correspond to the allocation mode). ${ }^{1} \mathrm{H}$ NMR $\left(300 \mathrm{MHz}, \mathrm{DMSO}_{-} \mathrm{d}_{6}\right) \delta$, ppm: 1.25 (s, 18H, 6CH $) ; 8.75$ (s, 1H, Ar-H); 8.90 (s, $1 \mathrm{H}, \mathrm{Ar}-\mathrm{H}$ ). Elemental analysis was performed on standard equipment for microanalysis. Calculated $\left(\mathrm{C}_{18} \mathrm{H}_{20} \mathrm{Cl}_{2} \mathrm{O}_{8}\right)$ : C $49.67 \%$; H $4.63 \%$; Cl $16.29 \%$. Found: $\mathrm{C} 49.23 \%$; H $4.52 \%$; $\mathrm{Cl} 16.50 \%$.

\subsection{Synthesis of Poly(N-Methacryloyl-L-Proline)}

$\mathrm{N}$-methacryloyl proline was synthesized similarly to the method described in [32]. L-Proline (11.5 g, $0.1 \mathrm{~mol}$ ) was dissolved in $60 \mathrm{ml}$ of $2 \mathrm{M} \mathrm{NaOH}$ solution, and stirred at $273 \mathrm{~K}$, while methacryloyl chloride (10.4 g, $0.1 \mathrm{~mol}$ ) and $60 \mathrm{ml}$ of $2 \mathrm{M} \mathrm{NaOH}$ were added dropwise within $30 \mathrm{~min}$. The mixture was stirred for $2 \mathrm{~h}$ at room temperature and then the solution was acidified by addition of concentrated $\mathrm{HCl}(\approx 20 \mathrm{ml})$. After $2 \mathrm{~h}$, the precipitate formed was filtered out and washed by distilled water. After filtering the product was recrystallized from ethanol. The yield was above $80 \%$. 


\subsection{Preparation of Coatings}

\subsubsection{Modification of glass surfaces with di-chloroanhydride of di-tert-butylperoxy pyromellitate}

The procedure for modification is sketched in Scheme 1. Glass plates $(20 \mathrm{~mm} \times 20 \mathrm{~mm})$ were dipped into $0.2 \%(\mathrm{w} / \mathrm{w})$ methanolic solution of APTES for $24 \mathrm{~h}(1)$. After incubation, weakly-bound silane molecules were removed by methanol extraction in a Soxhlet apparatus. Then the plates functionalized with APTES were dipped into $1 \%$ solution of peroxide in dry 1,4-dioxane for $24 \mathrm{~h}$ (2). Weakly-bound peroxide was removed by dioxane extraction in a Soxhlet apparatus during $4 \mathrm{~h}$. As a result, a monolayer of peroxide tethered to the aminated surfaces was obtained (3).

\subsubsection{Grafting of PNMP brushes}

Glass plates with surface-immobilized PI were placed in a container with $0.1 \mathrm{M}$ ethanol solution of NMP monomer and heated under an argon blanket at $363 \mathrm{~K}$ for a certain time $(6-48 \mathrm{~h})$ for graft-polymerization. Afterward, the plates with PNMP grafted (4) were washed with ethanol in a Soxhlet apparatus for $4 \mathrm{~h}$ followed by drying in ambient conditions.

\subsection{Characterization of Coatings}

\subsubsection{Water contact angle measurements}

Static contact angle experiments were performed by the sessile drop technique using a Kruss EasyDrop (DSA15) instrument with the Peltier temperaturecontrolled chamber. Contact angles were determined as the average of 10 measurements at different points on the plate surface.

To determine the fraction of the surface covered with PNMP brushes the Cassie-Baxter relationship [33, 34] was used:

$$
\cos \theta=x \cos \theta_{\text {peroxide }}+(1-x) \cos \theta_{\text {ami nated glass }}
$$

where $x$ and $(1-x)$ are two types of patches covering the surface with a real fraction.

\subsubsection{Ellipsometry}

Measurements were carried out with a serial nullellipsometer LEF-3 M, equipped with the "polarizercompensator-specimen-analyzer" arrangement, capable to determine the angular positions of polarization elements within $0.01^{\circ}$ accuracy. A He-Ne single-mode laser (light wavelength $\lambda=632.8 \mathrm{~nm}$ ) was used as a light source. Polarization parameters of light reflected from a sample (angles $\psi$ and $\Delta$ ) were determined using the two-zone technique (in the third and fourth measuring zone) for angle of incidence $\varphi$ varied between $58^{\circ}$ and $63^{\circ}$ (with a $1^{\circ}$ step). This $\varphi$-range, corresponding to the region of the pseudo-Brewster angle (where $\Delta \approx \pi / 2$ or $3 \pi / 2$ ), provides maximal sensitivity. The iterative procedure using monoand two-layer models was applied to fit the $(\psi, \Delta)$ data recorded under optimal experimental conditions [35] and yield average thickness $d$ (and refractive index $n$ ) for APTES and peroxide-graft-PNMP coatings, respectively. Optical parameters were determined as the average of three measurements at different points.

The average molecular weights of the grafted PNMP brushes were calculated considering ellipsometry data and kinetic parameters of polymerization using equation:

$$
M=\frac{C_{p}}{C_{0}\left(1-e^{-k \tau}\right) \cdot n}
$$

where $M$ is the average molecular weight of the grafted PNMP brushes, $\mathrm{g} / \mathrm{mol} ; C_{p}$ is the surface concentration of the PNMP brushes at the surface, $\mathrm{g} / \mathrm{m}^{2} ; C_{0}$ is the initial concentration of peroxide groups of the initiator immobilized at the surface, $\mathrm{mol} / \mathrm{m}^{2} ; k$ is the rate constant for the first order decomposition of peroxide groups at $363 \mathrm{~K}\left(k=8.1 \cdot 10^{-6} \mathrm{~s}^{-1}\right) ; \tau$ is a polymerization time, s; and $n$ is an initiation efficiency of the graft polymerization to the surface [36].

\section{Results and Discussion}

The grafted PNMP brushes were prepared in a three-step process outlined in Scheme 1. Initially, the native glass surface (1) was modified with APTES in order to get aminated surface (2) with higher reactivity. Then, peroxide monolayer (3) was tethered via interaction of dichloroanhydride of di-tert-butylperoxy pyromellitate with amino groups of APTES layer. Finally, the PNMP brushes (4) were grafted applying polymerization of NMP initiated from the surface by immobilized peroxide.

Thicknesses of the grafted layers were estimated by ellipsometry. Average thicknesses of the APTES layer and monolayer of peroxide initiator, measured by ellipsometry, were equal to 0.5 and $1.5 \mathrm{~nm}$, respectively. The surface concentration of peroxide molecules $\left(C_{0}\right)$ in monolayer was calculated from ellipsometric data using the equation:

$$
C_{0}=\frac{h_{i} \cdot \rho_{i}}{M_{i}}
$$

where $h_{i}$ is the layer thickness measured by ellipsometry, $\mathrm{nm} ; \rho_{i}$ is the peroxide initiator bulk density $\left(\rho_{i}=1.3 \mathrm{~g} / \mathrm{cm}^{3}\right)$ and $M_{i}$ is the molecular weight of the peroxide initiator $\left(M_{i}=435 \mathrm{~g} / \mathrm{mol}\right)$. Calculated surface concentrations of the peroxide molecules and peroxide groups are $(4.4 \pm 0.1) \cdot 10^{-6}$ and $(8.8 \pm 0.2) \cdot 10^{-6} \mathrm{~mol} / \mathrm{m}^{2}$, respectively. 


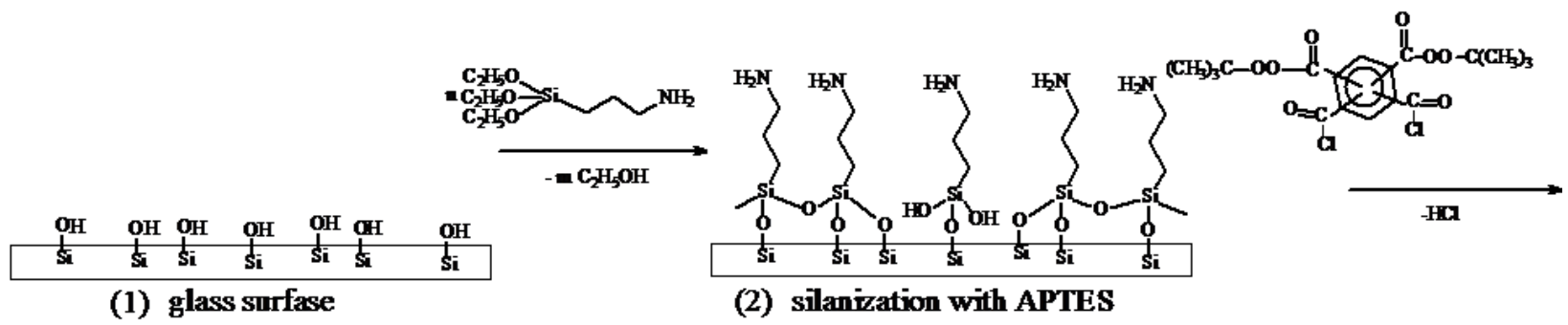

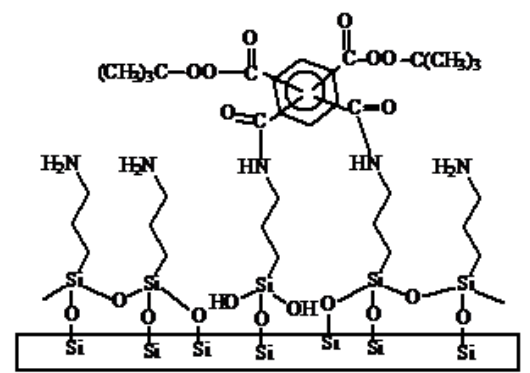

(3) peroxide grafted to aminated surfaces

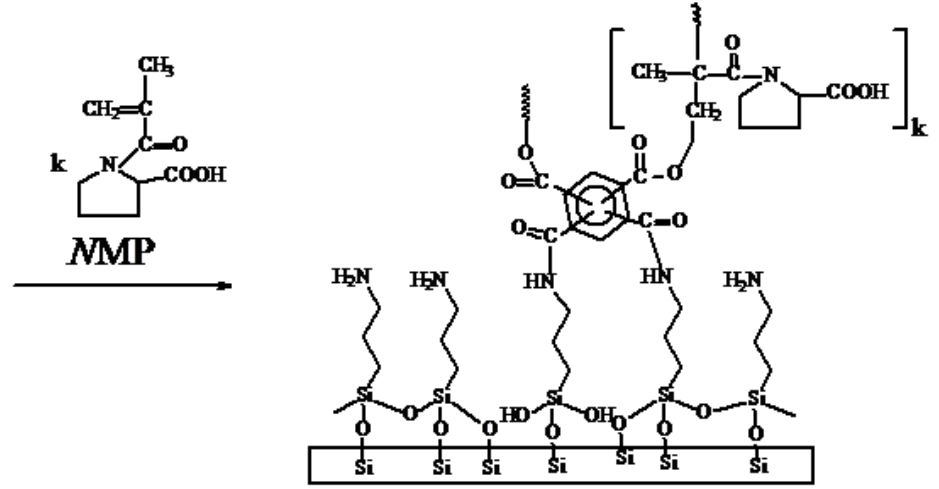

(4) PMMP brushes grafted to peroxide coating

Scheme 1. Strategy for synthesis of the grafted peptidomimetic polymer brushes at the glass surface (1) involves three main stages: surface amination (2) via interaction with APTES; tethering of peroxide initiator (3); and graft-polymerization of NMP initiated by immobilized initiator, resulting in PNMP brushes (4).

Under given conditions, the concentration of the peroxide initiator at the surface reached this maximum when $1 \%$ solution of peroxide initiator in dry 1,4-dioxane reacted with aminated surface for $24 \mathrm{~h}$.

The average thickness of PNMP brushes depended on polymerization time gradually increasing up to nearly $30 \mathrm{~nm}$ for $20 \mathrm{~h}$ (Fig. 1a), whereas the refractive index quickly reached the plateau value and afterward it did not changed in spite of further rise of PNMP thickness (Fig. 1b). The refractive index of the PNMP top covering after $48 \mathrm{~h}$ grafting was 1.497 .

Surface concentrations and grafting densities of PNMP in the grafted nanolayers were calculated from ellipsometry data (Table 1$)$. The grafting density $(\sigma)$ of PNMP chains at the glass surface was calculated using equation:

$$
\sigma=\frac{h \rho N_{A}}{M}
$$

where $\sigma$ is the grafting density, chains $/ \mathrm{nm}^{2} ; h$ is the dry layer thickness measured by ellipsometry, nm; $\rho$ is the PNMP bulk density, $\mathrm{g} / \mathrm{cm}^{3} ; N_{A}$ is Avogadro's number, $\mathrm{mol}^{-1}$, and $M$ is the average molecular weight of the PNMP brushes grafted to the surface, $\mathrm{g} / \mathrm{mol}$.

For calculation of the main parameters characterizing the PNMP nanolayers, namely an average molecular weight of the grafted brushes and their grafting density at the surface we used Eqs. (2) and (4), respectively. We assumed that initiation efficiency ( $n$ in Eq. (1)) for the peroxide initiator immobilized at the surface was equal to 0.1 [36] and remained constant throughout the process; and the initial concentration of peroxide groups at the surface $C_{0}=8.8 \cdot 10^{-6} \mathrm{~mol} / \mathrm{m}^{2}$. The calculated data are summarized in the Table.

As expected, the grafting density of PNMP brushes is rising with polymerization time and after $48 \mathrm{~h}$ it reaches approximately a half of chain per $1 \mathrm{~nm}^{2}$ of the surface, i.e. 1 chain occupies about $2 \mathrm{~nm}^{2}$ of the surface. Taking into consideration quite high molecular weight of the PNMP macrochains, such results can be achieved only if macrochains are strongly stretched forming brushes at the surface. Another important observation concerns the molecular weight of the grafted macrochains, as follows from the data presented in the Table, an increase in polymerization time brought about an essential lowering of their average molecular weight. This phenomenon can be explained by the fact that with increasing the grafting density the diffusion rate of monomer molecules to the radicals growing from the surface is slowed down, which in turn causes slowing of the propagation rate of the reaction and consequently leads to decrease of molecular weight of the macromolecules formed under these conditions. 

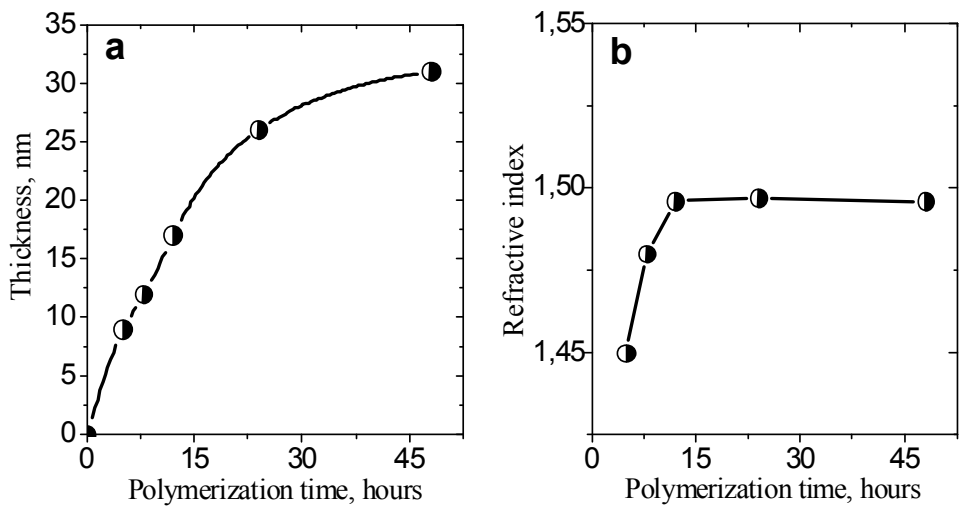

Fig. 1. Average thicknesses (a) and refractive indexes (b) of the PNMP nanolayers measured by ellipsometry $v s$. polymerization time

Effect of polymerization time on the parameters of the grafted poly(N-methacryloyl-L-proline) nanolayer

\begin{tabular}{|c|c|c|c|c|c|}
\hline $\begin{array}{c}\text { Polymerization } \\
\text { time, } \mathrm{h}\end{array}$ & $\begin{array}{c}\text { Thickness, } \\
\mathrm{nm}\end{array}$ & \multicolumn{2}{|c|}{ Surface concentration } & Average molecular & $\begin{array}{c}\text { Grafting densities, } \\
\text { chains } / \mathrm{nm}^{2}\end{array}$ \\
\cline { 3 - 4 } & $9 \mathrm{mg} / \mathrm{m}^{2}$ & $\mathrm{~mol} / \mathrm{m}^{2}$ & & 0.08 \\
\hline 5 & 9 & 10.9 & $0.6 \cdot 10^{-4}$ & 91 & 0.12 \\
\hline 8 & 12 & 14.5 & $0.7 \cdot 10^{-4}$ & 79 & 0.17 \\
\hline 12 & 17 & 20.6 & $1.1 \cdot 10^{-4}$ & 79 & 0.29 \\
\hline 24 & 26 & 31.5 & $1.7 \cdot 10^{-4}$ & 71 & 0.43 \\
\hline 48 & 31 & 37.5 & $2.0 \cdot 10^{-4}$ & 57 & $\mathrm{~mol}$ \\
\hline
\end{tabular}
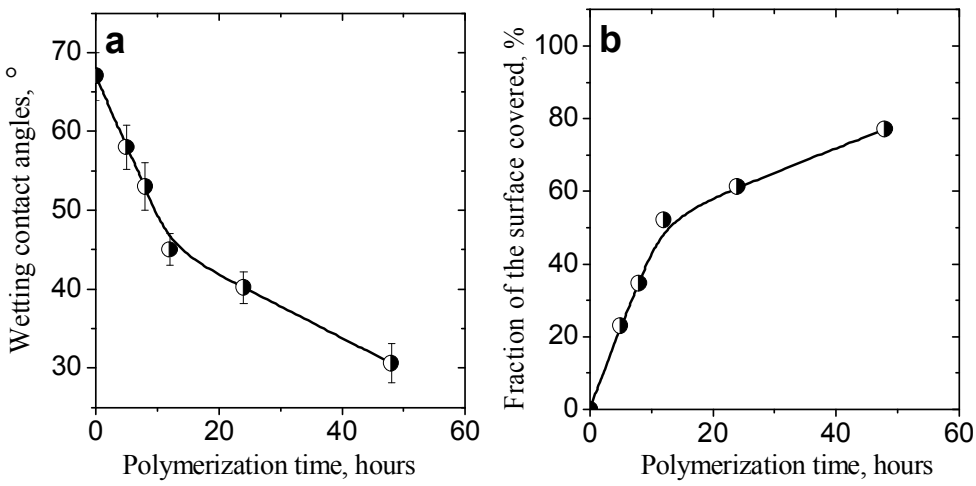

Fig. 2. Effect of polymerization time on receding water contact angles (a) and fraction of the surface covered with PNMP brushes determined using the Cassie-Baxter relationship (b)

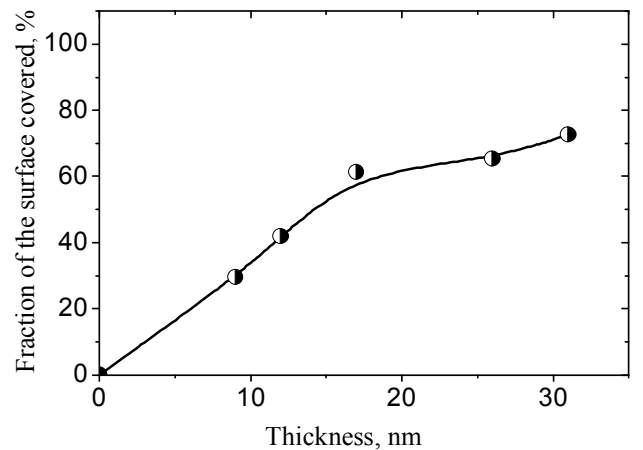

Fig. 3. Dependence of the effective coverage on thicknesses of the PNMP nanolayer measured by ellipsometry 
The effect of grafting time on the water receding contact angle at the glass surfaces modified with PNMP coating is shown in Fig. 2a. Glass surface demonstrates high hydrophility and consequently is characterized by low water contact angle; however when silanized, the glass surface loses its high hydrophility and the water contact angles rise up to $67^{\circ}$ (the point on the ordinate axis in Fig. 2a). The water contact angle for wetting of the "pure" poly(N-methacryloyl-L-proline) surface is low, just $16.1 \pm 2$ and its grafting onto the silanized glass surface should gradually reduces water contact angle due to its hydrophilization. The longer the polymerization time, the higher the quality of poly(N-methacryloyl-Lproline) grafted to the glass surface, and the lower the water contact angle; this is clearly seen from Fig. 2a.

Using Cassie-Baxter equation (Eq. (1)), the fraction of the glass surface covered with PNMP brushes has been estimated as a function of polymerization time (Fig. 2b). Analyzing these results, it can be concluded that the surface is covered incompletely; even after $48 \mathrm{~h}$ of modification, less than $80 \%$ of the surface was covered by PNMP.

The dependence of the fraction of the surface covering on the thickness of the grafted PNMP nanolayers has an inflection point (Fig. 3.), indicating some changes in morphology of the grafted polymer layers. The initial part of the curve is almost linear up to about $17 \mathrm{~nm}$ of thickness determined ellipsometrically but further thickness growth has much smaller effect on the fraction of covered surface. A possible reason for this phenomenon is that the grafted PNMP nanolayer has a relatively loose structure even at high grafting density and a complete covering can be achieved only for quite thick PNMP layers.

\section{Conclusions}

The novel peptidomimetic coatings consisting of poly(N-methacryloyl-L-proline) brushes grafted to the glass surface were synthesized using graft-polymerization of N-methacryloyl-L-proline initiated from the surface by immobilized peroxide initiator while the latter was tethered to the previously aminated glass plates. Investigation of PNMP nanolayers by means of ellipsometry revealed that both its thickness and the grafting density of brushes increased with polymerization time. Grafting of the PNMP brushes brought about a gradual diminishing of the water contact angle of the surface modified. However, the calculation of the surface covering fraction showed that surface was covered incompletely, even at quite high grafting density $\left(0.43\right.$ macrochain per $\left.\mathrm{nm}^{2}\right)$ fraction of covering did not exceed $80 \%$, probably due to the formation of PNMP nanolayers with relatively loose structure in these conditions. The synthesized PNMP coatings may have a great potential for medical and biotechnological applications as protein capture agents and supports for cell growing.

\section{Acknowledgments}

We thank Prof. Volodymyr Donchak and Dr. Khrystyna Harhay from the Lviv Polytechnic National University, Lviv, Ukraine for peroxide-containing initiator.

\section{References}

[1] Motornov M., Roiter Y., Tokarev I., Minko S.: Prog. Polym. Sci., 2010, 35, 174. https://doi.org/10.1016/j.progpolymsci.2009.10.004

[2] Tokarev I., Gopishetty V., Zhou J. et al.: Appl. Mater. Interfaces, 2009, 1, 532. https://doi.org/10.1021/am800251a

[3] Lee H., Pietrasik J., Sheiko S., Matyjaszewski K.: Prog. Polym. Sci., 2010, 35, 24. https://doi.org/10.1016/j.progpolymsci.2009.11.002 [4] Cole M., Voelcker N., Thissen H., Griesser H.: Biomaterials, 2009, 30, 1827. https://doi.org/10.1016/j.biomaterials.2008.12.026

[5] Chen T., Ferris R., Zhang J. et al.: Prog. Polym. Sci., 2010, 35, 94. https://doi.org/10.1016/j.progpolymsci.2009.11.004

[6] Synytska A., Svetushkina E., Puretskiy N. et al.: Soft Matter, 2010, 6, 5907. https://doi.org/10.1039/C0SM00414F

[7] Luzinov I., Minko S., Tsukruk V.: Soft Matter, 2008, 4, 714. https://doi.org/10.1039/B718999K

[8] Fournier D., Hoogenboom R., Thijs H. et al.: Macromolecules, 2007, 40, 915. https://doi.org/10.1021/ma062199r

[9] Chen G., Hoffman A.: Nature, 1995, 373, 49.

https://doi.org/10.1038/373049a0

[10] Lee H., Pietrasik J., Matyjaszewski K.: Macromolecules, 2006,

39, 3914. https://doi.org/10.1021/ma060350r

[11] Zhang J., Peppas N.: Macromolecules, 2000, 33, 102.

https://doi.org/10.1021/ma991398q

[12] Garcia A., Marquez M., Cai T. et al.: Langmuir, 2007, 23, 224. https://doi.org/10.1021/la061632n

[13] Burkert S., Bittrich E., Kuntzsch M. et al.: Langmuir, 2010, 26, 1786. https://doi.org/10.1021/la902505q

[14] Mori H., Kato I., Endo T.: Macromolecules, 2009, 42, 4985. https://doi.org/10.1021/ma900706s

[15] Mori H., Iwaya H., Nagai A., Endo T.: Chem. Commun., 2005, 38, 4872. https://doi.org/10.1039/B509212D

[16] Mori H., Iwaya H., Endo T.: React. Funct. Polym., 2007, 67, 916. https://doi.org/10.1016/j.reactfunctpolym.2007.05.016

[17] Mori H., Iwaya H., Endo T.: Macromol. Chem. Phys, 2007, 208, 1908. https://doi.org/10.1021/ma902002b

[18] Mori H., Kato I., Matsuyama M., Endo T.: Macromolecules , 2008, 41, 5604. https://doi.org/10.1021/ma800181h

[19] Sanda F., Endo T.: Macromol. Chem. Phys., 1999, 200, 2651. https://doi.org/10.1002/(SICI)1521-

3935(19991201)200:12<2651::AID-MACP2651>3.0.CO;2-P

[20] Mori H., Endo T.: Macromol. Rapid Commun., 2012, 33, 1090. https://doi.org/10.1021/ma0509558

[21] Chung I., Britt P., Xie D. et al.: Chem. Commun., 2005, 28, 1046. https://doi.org/10.1039/B416591H

[22] Liu Z., Hu J., Sun J. et al.: J. Polym. Sci. A, 2010, 48, 3573. https://doi.org/10.1002/pola.24137

[23] Katakai R., Yoshida M., Hasegawa S. et al.: Macromolecules, 1996, 29, 1065. https://doi.org/10.1021/ma951094d

[24] Katakai R., Saito K., Sorimachi M et al.: Macromolecules, 1998, 31, 3383. https://doi.org/10.1021/ma971727j

[25] Raczkowska J., Ohar M., Stetsyshyn Y. et al.: Colloid. Surface B, 2014, 118, 270. https://doi.org/10.1016/j.colsurfb.2014.03.049

[26] Stetsyshyn Y., Raczkowska J., Budkowski A. et al.: Langmuir, 2016, 32, 11029. https://doi.org/10.1021/acs.langmuir.6b02946 
[27] Raczkowska J., Stetsyshyn Y., Awsiuk K. et al.: Appl. Surf. Sci., 2017, 407, 546. https://doi.org/10.1016/j.apsusc.2017.03.001 [28] Riddick J.,. Bunger W, Sakano T., Weissenerger A.: Organic Solvents: Physical Properties and Methods of Purification. Wiley, New York 1986.

[29] Milas N., Surgenor D.: Am J. Chem. Soc, 1946, 68, 205. https://doi.org/10.1021/ja01206a017

[30] Bentolila A., Vlodavsky I., Ishai-Michaeli R.. et al.: J. Med. Chem, 2000, 43, 2591. https://doi.org/10.1021/jm000089j

[31] Bayer O., Houben J., Muller E.: Methoden der organischen Chemie (Houben-Weyl), G. Thieme, Stuttgart, 1952, 8, 464.

[32] Wang X., Gan H., Zhang M., Sun T.: Langmuir, 2012, 28, 2791. https://doi.org/10.1021/la204143g

[33] Cassie A.: Discuss. Faraday Soc, 1948, 3, 11.

https://doi.org/10.1039/DF9480300011

[34] Swain P., Lipowsky R.: Langmuir, 1998, 14, 6772.

https://doi.org/10.1021/la980602k

[35] Bootsma G., Meyer F.: Surf. Sci, 1969, 14, 52.

https://doi.org/10.1016/0039-6028(69)90045-4

[36] Voronov S., Varvarenko S.: Peroksydovani Makromolekuly na Mezhi Rozdilu Faz. Vyd-vo LPNU, Lviv 2011.

Received: July 03, 2019 / Revised: September 02, 2019 / Accepted: December 02, 2019

\section{СИНТЕЗ, СТРУКТУРА І ВЛАСТИВОСТІ ПРИЩЕПЛЕНИХ ПОЛІМЕРНИХ ЩІТОК НА ОСНОВІ ПОЛІ(N-МЕТАКРИЛОЇЛ-L-ПРОЛІНУ)}

Анотація. Розроблено новий підхід до синтезу на поверхні амінованого скла нових біологічно сумісних полімерних наношарів на основі полі(N-метакрилоӥл-L-проліну). Прочес формування полімерних наношарів проводили в декілька стадій. Спочатку поверхню скла модифікували аміносиланом АПТЕС, в подальшому до утвореного амінованого моношару прищеплювали пероксидовмісний ініціатор (ПІ) на основі піромелітової кислоти. Іммобілізований ПІ використовували для ініціювання прищеплювальної "від поверхні" радикальної полімеризації $N$-метакрилоїл-L-проліну для отримання пептидімітуючих полімерних щіток. У роботі висвітлено особливості перебігу реакиії та оптимізовані умови ї̈ проведення. Наведені прищепленні покриття на основі щіток полі $(N-$ метакрилоїл- $L$ проліну) $\epsilon$ багатообічяючим матеріалом для багатьох застосувань у наномедичині, зокрема для створення імплантів та систем контрольованої взаємодії з білками та клітинами.

Ключові слова: синтез полімерних наномарів, прищеплювальна "від поверхні" полімеризачія, полімерні щчітки, полі(N-метакрилоїл-L-пролін), модифікація поверхні. 